\title{
PHARMACOLOGICAL APPROACH TO GLYCEMIC TREATMENT USING BLACK, GREEN AND HERBAL TEA EXTRACTS
}

\author{
K AKhter*, T Ghous ${ }^{1}$, Zain-Ul-Abdin, E SAdaf, A Hassan, \\ V IRSHAD AND S ANDLEEB ${ }^{2}$ \\ Department of Chemistry, University of Azad Jammu and Kashmir, \\ Muzaffarabad-13100, Pakistan
}

Keywords: Hyperglycemia, Alpha glucosidase inhibition, Amylase inhibition

\begin{abstract}
Tea is the second most widely used drink all over the world after water. It has several health benefits. The aqueous and methanolic extracts of black, green and herbal teas for the treatment of hyperglycemia and its associated complications were investigated. Nine tea samples including black, green and herbal teas namely Lipton black tea (LBT), Supreme black tea (SBT), Tapal black tea (TBT), Jasmine green tea (JGT), Lemon grass green tea (LGrT), Lemon green tea (LGT), Berginia ciliata, Bistorta affinis and Paeonia emodi were selected for the study. Total phenolic contents (TPC), total flavonoid contents (TFC), antioxidant properties including inhibitory activity against 2,2'-azino-bis (3-ethylbenzothiazoline-6-sulphonic acid) radical $\left(\mathrm{ABTS}^{\circ+}\right)$, iron chelation and enzymes inhibitory potential for alpha glucosidase and alpha amylase were analyzed based on in vitro assays. The percentage yield of extracts was in the range of 7.2 to $47 \%$. Methanolic extracts showed greater TPC values $(\mu \mathrm{g}$ GAE/g) while aqueous extracts showed greater TFC values ( $\mu \mathrm{g}$ Rutin $\mathrm{E} / \mathrm{g}$ ). The aqueous extracts of most of the studied tea samples showed strong biological activities with very low $\mathrm{IC}_{50}\left(50 \%\right.$ inhibitory concentration) values $(0.2-69.0 \mu \mathrm{g} / \mathrm{ml})$ for $\mathrm{ABTS}^{*+}$ radical scavenging, $\mathrm{Fe}^{2+}$ chelation and alpha glucosidase inhibition assays. For amylase inhibition activity, some aqueous extracts including LBT, SBT, JGT and $P$. emodi exhibited greater $\mathrm{IC}_{50}$ values.
\end{abstract}

\section{Introduction}

Hyperglycemia is a chronic disorder with rapidly increasing prevalence. The total predicted increase in number of people with hyperglycemia from 2012 to 2030 is about 180 million, a surprising increase of $48 \%$ at an annual growth of $2.7 \%$, which is twice than annual growth of the total world adult population. According to the international diabetes federation (IDF) in 2012 about 5 million people died as a result of hyperglycemia and its related complications (Liyanage et al. 2015). Insulin deficiency due to the inadequate beta cell mass is the cause of hyperglycemia (Remedi and Emfinger 2016). Diabetes produces long-term complications in the patients, affecting eyes, skin, kidney, nerves and blood vessels. The oxidative stress may contribute to the pathogenesis of diabetes by increasing insulin resistance or impairing insulin secretion (Pitocco et al. 2014). The human body is constantly subjected to significant oxidative stress which results imbalance between antioxidative system and the formation of reactive oxygen species (ROS) like singlet oxygen, superoxide anions $\left(\mathrm{O}_{2}{ }^{-}\right)$, hydrogen peroxide $\left(\mathrm{H}_{2} \mathrm{O}_{2}\right)$ and hydroxyl radical $(\mathrm{OH})$ which cause diabetes (Reinmuth-Selzle et al. 2017). Antioxidants are effective in reducing diabetic complications indicating that it may be beneficial either by ingestion of natural antioxidants or through dietary supplementation (Dasgupta and Klein 2014). Moreover, the hydrolysis of dietary polysaccharide like starch is an important cause of hyperglycemia. Two key

*Author for correspondence: <kulsoom.chem@gmail.com>. ${ }^{1}$ Department of Chemistry, Mirpur University of Science and Technology, Mirpur-10250, Pakistan. ${ }^{2}$ Department of Zoology, University of Azad Jammu and Kashmir, Muzaffarabad, Pakistan. 
enzymes including alpha amylase and alpha glucosidase secreted by pancreas and intestine, respectively in the digestive system catalyze the hydrolysis of starch during its digestion and increase the blood glucose level. Inhibition of these enzymes slow down carbohydrate absorption, which delay digestion and results in decreasing the rate of glucose absorption (Mahmood 2016). Drugs like voglibose, miglitol and acarbose are used as inhibitors of these enzymes but these drugs show limitations including adverse side effects like flatulence, abdominal distention, meteorism and diarrhea (Oboh et al. 2015) and secondary failure or the inability to halt further loss of insulin secretory capacity. Therefore, modern, effective and cheap medicines are the requirements of the present time. One possible way is the use of herbal remedies which appear to be widely used with relatively fewer documented side effects (American Diabetes Association 2017). Tea is the most popular drink all over the world and is cultivated in more than 30 countries including Pakistan. In Pakistan, per capita tea consumption is about $1 \mathrm{~kg}$. It is beneficial for human health due to high content of antioxidants mainly flavonols, catechins, polyphenols (Nash and Ward 2017) and is beneficial for the reduction of oxidative damage to brain. Two major types of Pakistani teas are green and black tea that differ in their composition and production method (Koch et al. 2018). In the region of AJK, tea is a very popular drink among the people. In addition, the extracts of many native herbal species including B. ciliata, B. affinis and P. emodi are also used as tea for the treatment of different ailments. Tea has many health benefits due to the presence of various biologically active compounds. The in vivo and in vitro studies supported antihyperglycemic and anti-oxidant effects of tea (Nashiela et al. 2015, Li et al. 2019).

The potential of aqueous and methanolic extracts of green and black tea samples available in local market and the roots of native herbal teas used by the local people of Azad Jammu and Kashmir (AJK) region for managing hyperglycemia and related oxidative dysfunction were investigated and compared. So far a comparative analysis of aqueous and methanolic extracts of green, black and native herbal teas has not been reported yet. Thus an attempt was made to investigate the aqueous and methanolic extracts of black, green and herbal teas for the treatment of hyperglycemia and its associated complications.

\section{Materials and Methods}

All black and green tea samples were collected from local market of Muzaffarabad, the capital city of the AJK, Pakistan while selected herbs were collected from District Neelum of AJK. Methanolic and aqueous extracts of nine different tea samples including three black teas namely Lipton black tea (LBT), Supreme black tea (SBT) and Tapal black tea (TBT), three green teas namely Jasmine green tea (JGT), Lemon grass green tea (LGrT) and Lemon green tea (LGT) and three herbal teas B.ciliata, B. affinis and P. emodi were prepared using soxhelt extraction procedure. Solution $(1 \mathrm{mg} / \mathrm{ml})$ of each tea extract was prepared for the analysis of the desired activities. Quantitative phytochemical analysis of the extracts was performed by determining total phenolic content (TPC) using Folin-Ciocalteu method (Singleton et al. 1999) and total flavonoid content (TFC) using aluminum chloride by following the reported method (Kumar et al. 2008). TPC was investigated making standard calibration curve of gallic acid and expressed as $\mu \mathrm{g}$ GAE/g while TFC was calculated by making standard calibration curve of Rutin hydrate and expressed as $\mu \mathrm{g} \mathrm{RE} / \mathrm{g}$.

Antioxidant properties including free radical scavenging activity against 2,2'-azino-bis (3ethylbenzothiazoline-6-sulphonic acid) radical $\left(\mathrm{ABTS}^{\circ+}\right)$, iron chelation and enzyme inhibitory potential for the two key digestive enzymes including alpha glucosidase and alpha amylase for aqueous and methanolic extracts of all tea samples were investigated and compared using spectrophotometric methods. Both antioxidant and enzyme inhibition potentials were assessed 
based on in vitro assays. ABTS ${ }^{+}$radical scavenging activity for a range of extract concentration $(10-30 \mu \mathrm{g} / \mathrm{ml})$ was performed by using the method described by Seeram et al (2006) and ascorbic acid solution $(0.02-0.1 \mu \mathrm{g} / \mathrm{ml})$ was used as standard. Per cent radical scavenging activity (\%RSA) for each sample was calculated and concentration $\left(\mathrm{IC}_{50} \mu \mathrm{g} / \mathrm{ml}\right)$ of tea extracts and standard used to scavenge $50 \%$ of the free radicals was also calculated using percent radical scavenging activity (\% RSA) at five different concentrations of each tea extract. Metal chelating antioxidant assay was performed by using the method described by Chew et al (2009) which relies on the formation of red colored Ferrozine-ferrous ion complex. The range of extract concentration tested was 30-70 $\mu \mathrm{g} / \mathrm{ml}$ while gallic acid was used as standard and the concentration of tea extract used to chelate $50 \%$ of the metal ions $\left(\mathrm{IC}_{50}\right)$ was calculated using percent $\mathrm{Fe}^{2+}$ chelating potential at five different concentrations of each tea extract. $\alpha$-glucosidase inhibitory activity was measured using standard methods reported by Sancheti et al (2011) while $\alpha$-amylase inhibitory activity was carried out using modified 3,5-dinitro salicylic acid (DNS) method (Nickavar and Yousefian 2011). Acarbose was used as standard inhibitor of both the enzymes and the percent inhibition (\%I) potential was calculated at a concentration range of $10-150$ and $100-500 \mu \mathrm{g} / \mathrm{ml}$ of each extract for $\alpha$-glucosidase and $\alpha$-amylase respectively. The concentration of tea extract used to inhibit $50 \%$ of the enzyme activity $\left(\mathrm{IC}_{50}\right)$ was calculated using percent inhibition potential.

Antimicrobial activity against $E$. coli was performed using well diffusion method (Doughari and Manzara 2008).The microorganisms were inoculated with nutrient broth (Oxide: CM1) medium, incubated for $24 \mathrm{hrs}$ in a rotary shaker (Irmeco $\mathrm{GmbH}$, Germany) at $37^{\circ} \mathrm{C}$ and culture was mixed with freshly prepared nutrient agar $\left(\right.$ Oxide: $\left.\mathrm{CMOO}_{3}\right)$ medium at $45^{\circ} \mathrm{C}$. The mixture was poured in sterilized Petri plates and allowed to solidify. In each plate, wells (5 $\mathrm{mm}$ diameter) were made using sterilized micropipette tip and sterilized needle was used for the removal of agar plug. Approximately $30 \mu \mathrm{l}$ of each extract was placed in prepared wells in triplicates and the Petri plates were incubated at $37^{\circ} \mathrm{C}$ for $24 \mathrm{hrs}$. Ciprofloxacin was used as a standard while all solvents were also used as a negative control. Microbial growth was determined by measuring the zone of inhibition (ZOI, mm). The results of the sensitivity tests were expressed as (0) for no sensitivity, $(1-5 \mathrm{~mm})$ for low sensitivity, $(6-10 \mathrm{~mm})$ for moderate sensitivity and $(11-25 \mathrm{~mm})$ for high sensitivity.

\section{Results and Discussion}

Extraction yield of methanolic extracts of tea samples was: LBT (15\%), SBT (15.46\%), TBT (12.5\%), JGT (27.98\%), LGrT (7.2\%), LGT (22\%), B. ciliata (47\%), B. affinis (27\%), P. emodi (21\%) and for aqueous extracts was: LBT (20\%), SBT (17\%), TBT (15\%), JGT (28\%), LGrT (8\%), LGT (24\%), B. ciliata (48\%), B. affinis (30\%) and P. emodi (25\%). Both aqueous and methanolic extracts showed substantial percentage yield.

For the determination of TPC and TFC in extracts, standard calibration curves of gallic acid and rutin hydrate were developed respectively taking into consideration the relationship between absorbance and concentration. TPC and TFC as $\mu \mathrm{g}$ GAE/g and $\mu \mathrm{g} \mathrm{RE} / \mathrm{g}$ were determined from the calibration curves of gallic acid and rutin hydrate which were found to be linear in the range $0.05-0.25 \mu \mathrm{g} / \mathrm{ml}$ and $0.1-0.5 \mu \mathrm{g} / \mathrm{ml}$ with $\mathrm{y}=0.078 \mathrm{x}-0.075 ; \mathrm{R}^{2}=0.9987$ and $\mathrm{y}=0.040 \mathrm{x}-$ $0.0264 ; R^{2}=0.9974$, respectively. Results of the study presented in Table 1 demonstrate high values of TPC in methanolic extracts ranging $167-430 \mu \mathrm{g}$ GAE/g as compared to aqueous extracts with TPC values ranging 96 - $364 \mu \mathrm{g}$ GAE/g, while TFC values were found to be higher in aqueous extracts ranging $279-963 \mu \mathrm{g} \mathrm{RE} / \mathrm{g}$ when compared to methanolic extracts which showed TFC in range of $104-540 \mu \mathrm{g} \mathrm{RE} / \mathrm{g}$. In general, results of the study revealed that all studied extracts were rich sources of TPC and TFC. 
Table 1. TPC ( $\mu \mathrm{gGAE} / \mathrm{g})$ and TFC ( $\mu \mathrm{g}$ RutinE/g) of aqueous and methanolic extracts of black, green and herbal teas.

\begin{tabular}{llcccc}
\hline Tea sample & $\begin{array}{l}\text { Tea sample } \\
\text { code }\end{array}$ & \multicolumn{2}{c}{ TPC $(\mu \mathrm{g}$ GAE/g) } & \multicolumn{2}{c}{ TFC $(\mu \mathrm{g}$ RutinE/g) } \\
\cline { 2 - 5 } Black tea & $\begin{array}{c}\text { Aqueous } \\
\text { extract }\end{array}$ & $\begin{array}{c}\text { Methanolic } \\
\text { extract }\end{array}$ & $\begin{array}{c}\text { Aqueous } \\
\text { extract }\end{array}$ & $\begin{array}{c}\text { Methanolic } \\
\text { extract }\end{array}$ \\
\hline \multirow{5}{*}{ Green tea } & LBT & 219 & 303 & 624 & 357 \\
& SBT & 323 & 305 & 448 & 361 \\
& TBT & 364 & 430 & 457 & 428 \\
& JGT & 151 & 167 & 438 & 203 \\
& LGrT & 196 & 201 & 963 & 142 \\
& LGT & 231 & 245.5 & 634 & 391 \\
& B. ciliata & 96 & 359 & 500 & 280 \\
& B. affinis & 210 & 361 & 861 & 543 \\
& P. emodi & 175 & 296 & 279 & 104 \\
\hline
\end{tabular}

$\mathrm{ABTS}^{\bullet^{+}}$free radical is captured by electron transfer from antioxidants present in the extracts. The relation observed in $\mathrm{ABTS}^{*+}$ radical scavenging activity was dose dependent. With increase in concentration of extract, the antioxidant activity was also increased. $\mathrm{IC}_{50}$ values of each extract were calculated and presented in Table 2.

Ascorbic acid showed $98.17 \%$ of $\mathrm{ABTS}^{\circ+}$ radical scavenging potential at studied concentration of $0.1 \mu \mathrm{g} / \mathrm{ml}$. It was observed that most of the methanolic extracts showed very low $\mathrm{IC}_{50}$ values in comparison to their aqueous counterparts except SBT, TBT and LGT where aqueous extracts provided low $\mathrm{IC}_{50}$ values of $4.0,0.2$ and $1.0 \mu \mathrm{g} / \mathrm{ml}$, respectively in comparison to their methanolic extracts. Aqueous extracts of TBT, LGT and B. affinis showed low $\mathrm{IC}_{50}$ values of $0.2,1.0$ and $1.0 \mu \mathrm{g} / \mathrm{ml}$, respectively when compared to ascorbic acid which is a standard and provided $\mathrm{IC}_{50}$ of $1.03 \mu \mathrm{g} / \mathrm{ml}$. Methanolic extracts of two herbal tea samples, B. ciliata and $B$. affinis showed low $\mathrm{IC}_{50}$ values as 0.4 and $1.0 \mu \mathrm{g} / \mathrm{ml}$, respectively in comparison with ascorbic acid. Both the extracts of $B$. ciliata showed low $\mathrm{IC}_{50}$ values than ascorbic acid. These results indicated stronger $\mathrm{ABTS}^{*+}$ scavenging potential of the samples which could be explained due to the presence of high TFC.

In vitro, Ferrozine quantitatively chelates with $\mathrm{Fe}^{2+}$ and results in formation of the red colored complex. Antioxidants present in the plant extract reduce this chelating activity by forming complex with metal resulting in decreasing the intensity of color. Thus, the measurement of color reduction leads to the estimation of the chelating potential of the agent. All the tea extracts have shown interference with the formation of ferrozine- $\mathrm{Fe}^{2+}$ complex. The ferrous metal ion chelating potential of aqueous extracts was higher due to the presence of high TFC. $\mathrm{Fe}^{2+}$ chelation was expressed as $\mathrm{IC}_{50}$ values and a comparative analysis of $\mathrm{IC}_{50}$ values of $\% \mathrm{Fe}^{2+}$ chelating activity of methanolic and aqueous extracts of tea samples is presented in Table 2. Low $\mathrm{IC}_{50}$ values were obtained for aqueous extracts of all black and green tea samples except LGrT which showed high $\mathrm{IC}_{50}$ for its aqueous extract $(69.0 \mu \mathrm{g} / \mathrm{ml})$. Aqueous extracts of all herbal tea samples showed very high $\mathrm{IC}_{50}$ values compared to their methanolic extracts. Aqueous extracts of JGT and LGT showed low and comparable $\mathrm{IC}_{50}$ values of 4.0 and $19.4 \mu \mathrm{g} / \mathrm{ml}$, respectively than standard gallic acid (14.0 $\mu \mathrm{g} / \mathrm{ml})$ while aqueous extracts of LBT $(32.0 \mu \mathrm{g} / \mathrm{ml})$, SBT $(41.0 \mu \mathrm{g} / \mathrm{ml})$, TBT $(36.0 \mu \mathrm{g} / \mathrm{ml})$, and LGrT $(69.0 \mu \mathrm{g} / \mathrm{ml})$ showed $\mathrm{IC}_{50}$ values slightly higher than gallic acid. Very high $\mathrm{IC}_{50}$ values were obtained for aqueous extracts of all herbal tea samples especially B. affinis $(340.0 \mu \mathrm{g} / \mathrm{ml})$ and $P$. emodi $(490.0 \mu \mathrm{g} / \mathrm{ml})$. 


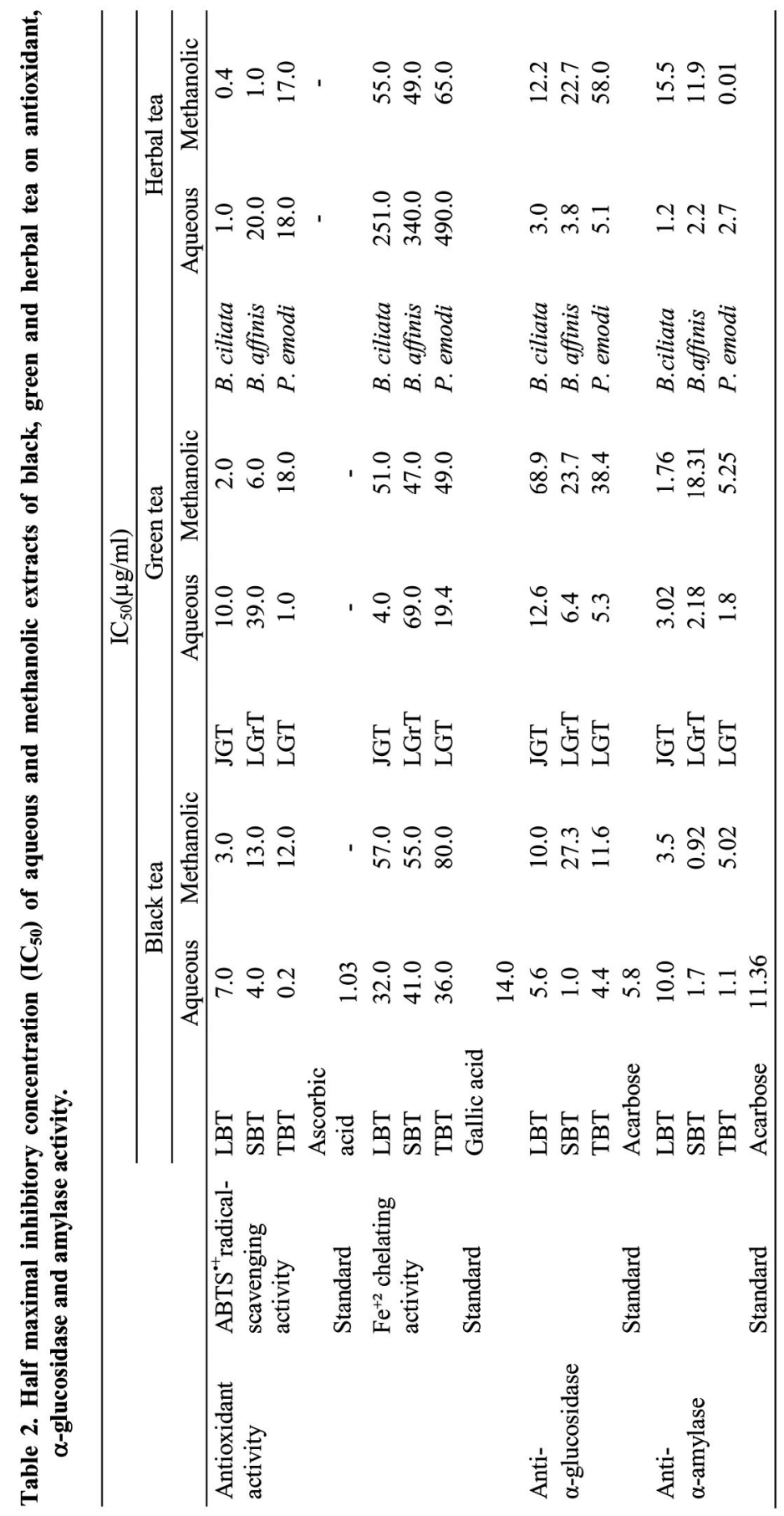


$\alpha$-glucosidase inhibitors can retard the uptake of dietary carbohydrates and suppress postprandial hyperglycemia. $\alpha$-glucosidase acts upon substrate $p$-nitro phenyl- $\alpha$-Dglucopyranoside and results in the conversion of substrate to nitro phenol and D-glucose. In the presence of inhibitors, $\alpha$-glucosidase activity is reduced due to accommodation of active sites by inhibitors and glucose formation was found to decrease (Kasturi et al. 2017). Acarbose showed strong inhibitory activity against $\alpha$-glucosidase with $\mathrm{IC}_{50}$ value of $5.8 \mu \mathrm{g} / \mathrm{ml}$. This finding is consistent with the previous study of Sulistiyani et al. (2016) who reported smaller acarbose $\mathrm{IC}_{50}$ value of $2.154 \mu \mathrm{g} / \mathrm{ml}$. The crude aqueous extracts of all tea samples showed high $\alpha$-glucosidase inhibitory activity. Low $\mathrm{IC}_{50}$ values were obtained especially for the aqueous extracts of SBT (1.0 $\mu \mathrm{g} / \mathrm{ml})$, TBT $(4.4 \mu \mathrm{g} / \mathrm{ml})$, B. ciliata $(3.0 \mu \mathrm{g} / \mathrm{ml})$ and B. affinis $(3.8 \mu \mathrm{g} / \mathrm{ml})$ compared to acarbose. Aqueous extracts of LBT $(5.6 \mu \mathrm{g} / \mathrm{ml})$, LGrT $(6.4 \mu \mathrm{g} / \mathrm{ml})$, LGT $(5.3 \mu \mathrm{g} / \mathrm{ml})$ and P. emodi $(5.1$ $\mu \mathrm{g} / \mathrm{ml})$ presented comparable $\mathrm{IC}_{50}$ values to the standard acarbose. Based on $\mathrm{IC}_{50}$ values, the aqueous extracts of all samples were found to be potential enzyme inhibitor than their methanolic extracts. The inhibition of this enzyme can be achieved by various natural compounds such as the phenolic group, the flavonoids, luteolin, miricetin, and quercetin (Tadera et al. 2006).

The $\alpha$-amylase inhibition potential of aqueous and methanolic extracts of all tea samples was significantly higher with low $\mathrm{IC}_{50}$ values compared to the standard acarbose with $\mathrm{IC}_{50} 11.36 \mu \mathrm{g} / \mathrm{ml}$. Only methanolic extracts of LGrT $(18.31 \mu \mathrm{g} / \mathrm{ml})$ and B. ciliata $(15.51 \mu \mathrm{g} / \mathrm{ml})$ showed greater $\mathrm{IC}_{50}$ values compared to acarbose. Zone of Inhibition (ZOI) data obtained for antimicrobial activity showed that the tea samples have no significant activity against $E$. coli at studied concentration of $1 \mathrm{mg} / \mathrm{ml}$ (Table 3). It was observed that aqueous and methanolic extracts of herbal tea samples revealed slight antibacterial activity with zone of inhibition 4.5-5.0 $\mathrm{mm}$. However, black and green tea samples did not showed any remarkable sensitivity.

Table 3. Zone of inhibition (mm) for black, green and herbal teas against $E$. coli.

\begin{tabular}{|c|c|c|c|c|c|c|c|c|}
\hline & \multicolumn{8}{|c|}{ Zone of inhibition (mm) } \\
\hline & \multicolumn{2}{|c|}{ Black tea } & & \multicolumn{2}{|c|}{ Green tea } & & \multicolumn{2}{|c|}{ Herbal tea } \\
\hline & $\begin{array}{l}\text { Aqueous } \\
\text { extract }\end{array}$ & $\begin{array}{l}\text { Methanolic } \\
\text { extract }\end{array}$ & & $\begin{array}{l}\text { Aqueous } \\
\text { extract }\end{array}$ & $\begin{array}{l}\text { Methanolic } \\
\text { extract }\end{array}$ & & $\begin{array}{l}\text { Aqueous } \\
\text { extract }\end{array}$ & $\begin{array}{l}\text { Methanolic } \\
\text { extract }\end{array}$ \\
\hline LBT & 2.0 & 3.0 & JGT & 0.0 & 0.0 & B. ciliata & 4.5 & 5.0 \\
\hline SBT & 0.0 & 0.0 & LGrT & 0.0 & 0.0 & B. affinis & 4.5 & 5.0 \\
\hline TBT & 0.5 & 1.0 & LGT & 1.0 & 1.0 & P. emodi & 4.5 & 5.0 \\
\hline $\begin{array}{l}\text { Cipro- } \\
\text { floxacin }\end{array}$ & 20.0 & 20.0 & $\begin{array}{l}\text { Cipro- } \\
\text { floxacin }\end{array}$ & 20.0 & 20.0 & $\begin{array}{l}\text { Cipro- } \\
\text { floxacin }\end{array}$ & 20.0 & 20.0 \\
\hline
\end{tabular}

In this study, antioxidant, enzyme inhibition and antimicrobial activities of aqueous and methanolic extracts of green, black and herbal teas have been demonstrated. Aqueous extracts of all tea samples showed strong potential as compared to their methanolic extracts with very low $\mathrm{IC}_{50}$ values. Ranking based on biological potential of three different types of teas used in this study was as: black teas > green teas > herbal teas. Overall, current research findings indicated that the regular intake of tea is potentially beneficial for the prevention of oxidation-linked diseases, to control postprandial hyperglycemia and it also provides antioxidant defense to the patients with type-2 diabetes mellitus and maintain overall health. Moreover, in comparison with methanolic extracts, aqueous extracts of these teas could be explored for their potential applications in the treatment of diabetes associated problems. 


\section{Acknowledgements}

Authors are thankful to the University of Azad Jammu and Kashmir, Muzaffarabad for providing lab facilities and Higher Education Commission, Pakistan for financial support.

\section{References}

American diabetes association. Standards of medical care in diabetes. Diabetes Care. 2017. 40: S33-S43.

Chacko SM, Thambi PT, Kuttan R and Nishigaki I 2010. Beneficial effects of green tea: A literature review. Chinese Medicine 5(1): 13.

Chew YL, Goh JK and Lim YY 2009. Assessment of in vitro antioxidant capacity and polyphenolic composition of selected medicinal herbs from Leguminosae family in Peninsular Malaysia. Food Chem. 116(1): 13-18.

Dasgupta A and Klein K 2014. Chapter 16 - Herbal and Other Dietary Supplements That Are Antioxidants. Antioxidants in Food, Vitamins and Supplements. San Diego, Elsevier: 295-315.

Doughari J and Manzara S 2008. In vitro antibacterial activity of crude leaf extracts of Mangifera indica Linn. African J. Microbiol. Res. 2(1): 67-72.

Kasturi SP, Sujatha S, Srinivas U and Anireddy J 2017. Synthesis and $\alpha$-glucosidase inhibition activity of dihydroxy pyrrolidines. Bioinorg. Med. Chem. Letters. 27(12).

Koch W, Koch WK, Komsta L, Marzee Z, Swerc W and Glowniak K 2018. Green tea quality evaluation based on its catechins and metals composition in combination with chemometric analysis. Molecules 23(7): 1689.

Kumar S, Kumar D, Saroha K, Singh N and Vashishta B 2008. Antioxidant and free radical scavenging potential of Citrullus colocynthis (L.) Schrad. methanolic fruit extract. Acta Pharmaceut. 58(2): 215220.

Lambert JD and Elias RJ 2010. The antioxidant and pro-oxidant activities of green tea polyphenols: a role in cancer prevention. Arch. Biochem. and Biophys. 501(1): 65-72.

Li R, Zhang Y, Rasool S, Geetha T and Babu JR 2019. Effects and Underlying Mechanisms of Bioactive Compounds on Type 2 Diabetes Mellitus and Alzheimer's Disease. Oxid Med Cell Longev. doi: $10.1155 / 2019 / 8165707$

Liyanage T, Ninomiya T, Jha V, Neal B, Patrice HM, Okpechi I, Zhao MH, Lv J, Garg AX, Knight J, Rodgers A, Gallagher M, Kotwal S, Cass A and Perkovic V 2015. Worldwide access to treatment for end-stage kidney disease: a systematic review. The Lancet 385(9981): 1975-1982.

Mahmood N 2016. A review of $\alpha$-amylase inhibitors on weight loss and glycemic control in pathological state such as obesity and diabetes. Comparat. Clin. Pathol. 25(6): 1253-1264.

Nash LA and Ward WE 2017. Tea and bone health: Findings from human studies, potential mechanisms, and identification of knowledge gaps. Critical Rev. Food Sci. Nutrit. 57(8): 1603-1617.

Nashiela FD, Abdullah N, Hashim N, Azizah AH 2015. Antioxidant activity of herbal tea prepared from Cosmos caudatus leaves at different maturity stages. Int. Food Res. J. 22(3): 1189-1194

Nickavar B and Yousefian N 2011. Evaluation of $\alpha$-amylase inhibitory activities of selected antidiabetic medicinal plants. Journal für Verbraucherschutz und Lebensmittelsicherheit 6(2): 191-195.

Oboh GM, Agunloye OM, Adefegha SA, Akinyemi AJ and Ademiluyi AO 2015. Caffeic and chlorogenic acids inhibit key enzymes linked to type 2 diabetes (in vitro): a comparative study. J. Basic Clin. Physiol. Pharmacol. 26:165.

Pitocco D, Martini F, Scavone G and Zaccardi F 2012. Oxidative Stress and Diabetes. Systems Biology of Free Radicals and Antioxidants. I. Laher. Berlin, Heidelberg, Springer Berlin Heidelberg: 3283-3317.

Reinmuth-Selzle K, Kampf CJ, Lucas K, Lang Yona N, Fröhlich Nowoisky J, Shiraiwa M, Lakey PS.J, Lai S, Liu F, Kunert AT, Ziegler K, Shen F, Sgarbanti R, Weber B, Bellinghausen I, Saloga J, Weller MG, Duschl A, Schuppan D and Pöschl U 2017. Air Pollution and Climate Change Effects on Allergies in the Anthropocene: Abundance, Interaction, and Modification of Allergens and Adjuvants. Environ. Sci. Technol. 51(8): 4119-4141. 
Remedi MS and Emfinger C 2016. Pancreatic $\beta$-cell identify in diabetes. Diabetes Obesity and Metabolism 18(1): 110-116.

Ritzel R 2009. Therapeutic approaches based on beta-cell mass preservation and/or regeneration. Frontiers in Biosci. 14: 1835-1850.

Sancheti S, Sancheti S, Lee SH, Lee JE and Seo SY 2011. Screening of Korean medicinal plant extracts for $\alpha$-glucosidase inhibitory activities. Iranian J. Pharma. Res. 10(2): 261.

Seeram NP, Henning SM, Niu Y, Lee R, Scheuller HS and Heber D 2006. Catechin and caffeine content of green tea dietary supplements and correlation with antioxidant capacity. J. Agricult. Food Chem. 54(5): 1599-1603.

Singleton VL, Orthofer R, Lamuela-Ravent'os RM 1999. Analysis oftotal phenols and other oxidation substrates and antioxidants by means of Folin-Ciocalteu reagent. Methods in Enzymol. 299: 152-178.

Sulistiyani, Safithri M, Sari YP. 2016. Inhibition of $\alpha$-glucosidase activity by ethanolic extract of Melia azedarach L. leaves. IOP Conference Series Earth and Environmental Science 31(1):012025.

Tadera K, Yuji M, Kouta T and Tomoko M 2006. Inhibition of $\alpha$-glucosidase and $\alpha$-amylase by flavonoids. J. Nutrit. Sci. Vitaminol. 52:149-153.

Venkatesh S, Reddy GD, Reddy YS, Sathyavathy D, Madhava RB 2004. Effect of Helicteres isora root extracts on glucose tolerance in glucose-induced hyperglycemic rats. Fitoterapia 75(3): 364-367.

(Manuscript received on 25 May, 2019; revised on 30 March, 2021) 